\title{
CUTTING PRACTICES IN WESTERN SPRUCE FORESTS
}

\author{
By J. D. CLARK ${ }^{1}$
}

INTRODUCTION

This paper will present the viewpoint of Western Canada, i.e. British Columbia and Alberta, with regard to the utilization of white and Engelmann spruces. To understand this viewpoint it is necessary to know the various forest types in which spruce is an associate species.

The Province of British Columbia, east of the Cascade Mountains, has a very diverse range of conditions under which spruce occurs. In the southern and eastern Interior of the province, on the wet sites about 3,500 feet elevation, spruce is associated with cedar, hemlock, larch, Douglas fir, alpine fir and lodgepole and white pines. On the elevated plateaus in this same region pure spruce types can be found in isolated small tracts; usually this one-species composition is restricted to immature age classes. In the mature-overmature types, alpine fir is an associate species.

In the northern Interior of the province, associate species of spruce are lodgepole pine, alpine fir and to a very limited extent, whitebark pine and Douglas fir.

The Province of Alberta does not have the complex type conditions of the Interior of British Columbia. Two forest regions in which merchantable spruce occurs are encompassed in Alberta, namely the Subalpine and Boreal regions. Associated species of spruce are lodgepole and jack pine, alpine and balsam fir, black spruce and poplar. In the southern foothills area, adjacent to the Rocky Mountains, whitebark pine and Douglas fir occur sparsely.

The northern Interior of British Columbia and the entire commercial forest region of Alberta, in a very broad sense, can be considered similar in species composition, terrain, and marketing and utilization factors.

The utilization of spruce in the area under discussion is related to economic factors. The available supply of timber for lumber, ties, veneer, poles and piling and other sawn products in North America is shrinking. Consequently, Interior British Columbia and Alberta, since they still support relatively large areas of forest suitable for the manufacture of such products, are, naturally, producers of the same products. However, such manufacturing utilizes only certain species and certain diameter classes, of the preferred species. There is at present little utilization of the so-called weed species -decadent hemlock and cedar, balsam and alpine fir, poplar and black spruce. Similarly, there is little utilization of the small-diameter-classes of all species. This uncut, small-diameter-class portion of logged stands is often erroneously termed the reserve crop, or the future cut.

These weed species and small-diameter residual trees are suitable for the manufacture of pulp and fibreboard products if it were economically feasible to produce them. At present there is only one pulp mill

\footnotetext{
${ }^{1}$ Assistant Chief Forester, Northwestern Pulp and Power Ltd., Hinton, Alberta.
} 
in operation, and one under construction, as well as one fibreboard plant in this vast area of Interior British Columbia and Alberta.

\section{Cutting Practices and Objectives}

\section{Strip, Block and Patch Clearcutting}

Throughout Interior British Columbia and Alberta, so-called clearcutting in strips, blocks and/or patches is currently in practice. These clearcutting layouts are being used to remove 50-80 percent of the total volume of the stands. They are classed as regeneration cuts. In many instances, however, the nomenclature of the cutting practice is misleading since the cutover area is not always wholly denuded of its crop.

In the northern Interior of British Columbia this system is expected to result in a cut of stand values approximating a minimum cutting diameter of 11 inches diameter at stump height with cutting below this standard optional. In the central Interior of the province the objective of the practice is to remove all merchantable trees in the cut area, and to retain an undisturbed adjacent residual stand.

In Alberta, the system is designed to remove 50 percent of the merchantable volume. In those areas being cut for pulpwood solely, or in conjunction with a cut for sawlogs, complete clearcutting of the cutting area is realized. It is rarely applied on cuts for sawlogs only.

In both British Columbia and Alberta a second cut, of the residual volumes, is proposed after a suitable regeneration period.

\section{Clearcut with Seed Blocks Reserved}

This is a regeneration cut. Its use is prescribed where a minimum seed source is desired to regenerate the cutover areas. Reserved blocks may or may not be cut after satisfactory regeneration is established on the initially-cut area. Such seed source reserve may involve 20 percent of the original stand volume. Utilization of the crop is similar to that described previously under practice "1".

\section{Partial Cutting Systems}

This broad category embodies cutting systems designed to remove a certain proportion of the merchantable stands on the basis of a single tree utilizaton. A specific percentage of the volume is designated for removal; a process of compilation is then used whereby the forester or forest manager works in reverse from the maximum stand diameter to a minimum diameter which will result in the required percent volume being removed. This cutting diameter limit will serve as a guide for marked selection cuts or will be specified as minimum diameter in diameter limit cutting.

\section{Diameter Limit}

This is an antiquated means of designating trees for removal. The objectives of cutting are to utilize a certain percentage of the volume initially and to leave the residual stand for seed source and/or a second cut in a specific number of years. It is a system of high grading. Its 
application is very widespread in both provinces under review. It is a system of expediency used to meet the demands for timber where staff limitations prevent the managing agency from applying a more intensive or more controlled system of single tree cutting. It is not my position here today to criticize this system-we know that its results are anything but good, but economics make it necessary, and, perhaps, acceptable. In Alberta, about 90 percent of all timber cut on Crown Lands, excluding pulpwood leases, is under a diameter limit system. The objective is to remove 40 percent of the total volume in the first cut, and to remove the residual volume after a suitable increment and/or regeneration period.

In Interior British Columbia the system is used to remove 45-70 percent of the volume with objectives similar to those in Alberta. The number of timber sales awarded under this cutting system, in the sprucebalsam types, is much less than in Alberta.

\section{Marked Single Tree Selection}

In British Columbia this system is used in uneven-aged, all-aged, mixed, immature or thrifty, mature stands. Usually 40-50 percent of stand volume is removed in the first cut. The objectives of cutting are removal of volume to result in an even-spaced, even-level canopy of thrifty residuals which can respond to release and/or provide a well-distributed seed source for regenerating the openings created by the first cut. In the latter objective, it can be considered a pseudo-shelterwood system. Application of the marked single-tree-selection system in the spruce-balsam types in British Columbia is quite popular, and of recognized merit. As evidenced by submission to the 1956 Royal Commission on Forestry, this system is also very controversial and somewhat unpopular among Interior British Columbia lumbermen.

In Alberta, almost identical objectives of application exist. The cut results in 40 percent removal of the merchantable volume with 60 percent being reserved for future cutting. The number of sales actually marked for cutting in this province is very small and would possibly represent 1-5 percent of the total number awarded annually. All sales sold under diameter-limit cutting, however, provide for marking if a diameter-limit cut is undesirable.

In conjunction with the above described cutting practices, scarification and planting of the cutover areas is gaining in popularity and use. Both are still used somewhat experimentally. In Alberta, the Forest Service allocated $\$ 25,000$ in 1959 for experimental scarification; a large pulp company has scarified some 3,000 cares of cutover land to date to determine if adequate and economical regeneration can be obtained. A reforestation clause is now becoming established, for inclusion in special large berths sold by the Alberta Forest Service, whereby $\$ 1.50$ per thousand board feet or equivalent is paid by the licensee to a Forest Service reforestation fund. This is in addition to stumpage dues. The area cut-over each year must be treated by the licensee to induce forest regeneration by scarification or other means subject to the approval of the Director of Forestry. If after six years of being logged, 1,000 seedlings of satisfactory species and distribution are established naturally, 
the money will be refunded, otherwise the Forest Service will use the money to aid in forest re-establishment.

Some Ranger Station nurseries, although small in size, are being established to provide local planting stock for regenerating cutover lands, although the emphasis on artificial reforestation will be by direct seeding.

In British Columbia scarification and planting is being used to restock cut-over spruce-balsam stands on a limited scale. In the Prince George District 90,000 seedlings were planted in 1959 . In the other Interior Districts planting in the spruce types is very limited.

Scarification is becoming a requirement of many timber sale contracts in Interior British Columbia. Such requirements specify that such work must be done in a seed year and also specify the amount that must be spent by the licensee on this work. In the Prince George District, scarification clauses have been included in eighteen timber sales; no restriction on year of scarification is made but it is stipulated that such work will be done at the time designated by the Forest Officer.

\section{CONCLUSION}

In summary, clearcutting systems are being used to a limited extent in the Western Canadian spruce types and their use is restricted mainly by economic factors. Partial cutting systems on a single-tree basis are very common, the diameter-limit system of removal being most widespread. Most second cuts are specified for removal in 20-40 years. If such a time lapse is allowed as a regeneration period in such treated stands and adequate regeneration is obtained, then perhaps we may consider this expedient system acceptable. However, I leave you with the question: "Can any forest manager afford such a long regeneration period when managing his forest on a sustained-yield basis?" 